\title{
Long term effects of inhaled corticosteroids in chronic obstructive pulmonary disease: a meta-analysis
}

P M van Grunsven, C P van Schayck, J P Derenne, H A M Kerstjens, T E J Renkema, D S Postma, T Similowski, R P Akkermans, P C M Pasker-de Jong, P N R Dekhuijzen, C L A van Herwaarden, C van Weel

Department of General Practice and Social Medicine P $M$ van Grunsven C P van Schayck R P Akkermans $C$ van Weel

Department of Epidemiology P C M Pasker-de Jong

Department of Pulmonology, Dekkerswald P N R Dekhuijzen C L A van Herwaarden

University of Nijmegen, The Netherlands

Department of Pulmonology, Hospital Pitié-Salpêtrière, Paris, France

J P Derenne

T Similowski

Department of Pulmonology, University of Groningen, The Netherlands H A M Kerstjens T E J Renkema D S Postma

Correspondence to: Dr P M van Grunsven, Department of General Practice, University of Nijmegen, P O Box 9101, 6500 HB Nijmegen, The Netherlands.

Received 25 November 1997 Returned to authors 21 January 1998 Revised manuscript received 27 April 1998 Accepted for publication 15 May 1998

\begin{abstract}
Background-The role of inhaled corticosteroids in the long term management of chronic obstructive pulmonary disease (COPD) is still unclear. A meta-analysis of the original data sets of the randomised controlled trials published thus far was therefore performed. The main question was: "Are inhaled corticosteroids able to slow down the decline in lung function $\left(\right.$ FEV $\left._{1}\right)$ in COPD?"

Methods-A Medline search of papers published between 1983 and 1996 was performed and three studies were selected, two of which were published in full and one in abstract form. Patients with "asthmatic features" were excluded from the original data. Ninety five of the original 140 patients treated with inhaled corticosteroids (81 with $1500 \mu \mathrm{g}$ beclomethasone daily, six with $1600 \mu \mathrm{g}$ budesonide daily, and eight with $800 \mu \mathrm{g}$ beclomethasone daily) and 88 patients treated with placebo (of the initial 144 patients) were included in the analysis. The effect on $\mathrm{FEV}_{1}$ was assessed by a multiple repeated measurement technique in which points of time in the study and treatment effects (inhaled corticosteroids compared with placebo) were investigated.
\end{abstract}

Results-No baseline differences were observed (mean age 61 years, mean $F_{1}$ $45 \%$ predicted). The estimated two year difference in prebronchodilator $\mathbf{F E V}_{1}$ was +0.0341 year $(95 \%$ confidence interval (CI) 0.005 to 0.063 ) in the inhaled corticosteroid group compared with placebo. The postbronchodilator $\mathrm{FEV}_{1}$ showed a difference of $+0.0391 /$ year $(95 \%$ CI -0.006 to $0.084)$. No beneficial effect was observed on the exacerbation rate. Worsening of the disease was the reason for drop out in four patients in the treatment group compared with nine in the placebo group. In the treatment group six of the 95 subjects dropped out because of an adverse effect which may have been related to the treatment compared with two of the 88 patients in the placebo group.
Conclusions-This meta-analysis in patients with clearly defined moderately severe COPD showed a beneficial course of $\mathrm{FEV}_{1}$ during two years of treatment with relatively high daily dosages of inhaled corticosteroids.

(Thorax 1999;54:7-14)

Keywords: chronic obstructive pulmonary disease; inhaled corticosteroids

The role of anti-inflammatory therapy (inhaled corticosteroids) is still unclear in the management of patients with stable chronic obstructive pulmonary disease (COPD). In contrast to asthma, several international consensus reports on the management of COPD mention that the evidence for beneficial effects of inhaled corticosteroids on lung function and symptoms has not yet been established. ${ }^{12}$ In asthma, inhaled corticosteroids have beneficial effects by reducing inflammation in the airways. Although inflammation seems to be present in the airway walls of patients with COPD (in terms of macrophages, $T$ cells, and neutrophils), the specific immunopathology is thought to be different from asthma. ${ }^{3}$ Short term treatment with both inhaled and systemic corticosteroids may have some beneficial effects on symptoms and lung function in subgroups of COPD patients, in particular those with partially reversible airways obstruction. ${ }^{4}$ Two long term uncontrolled and retrospective studies have shown that systemic corticosteroids slowed down the progression of decline in lung function in patients with moderate and severe COPD. ${ }^{56}$ The effects of prednisone were observed after 6-24 months, the effects being larger with doses of $10 \mathrm{mg}$ and higher. ${ }^{56}$ Especially in the long term, however, systemic corticosteroids may cause serious side effects. If long term treatment with corticosteroids is needed, it would therefore be preferable to replace systemic by inhaled corticosteroids. ${ }^{12}$

Thus far, three long term prospective clinical trials on inhaled corticosteroids in COPD have been published in full ${ }^{7-9}$ and two in abstract form. ${ }^{10}{ }^{11}$ All studies showed more or 
less beneficial effects of inhaled corticosteroids on the decline in lung function. In two of these studies it was shown that patients with "asthma features"-that is, high bronchodilator response and bronchial responsiveness-may respond better to inhaled corticosteroids. ${ }^{4}{ }^{12}$ However, the inclusion of "asthmatic" COPD patients in each of these studies may have caused an overestimation of the beneficial effects of inhaled corticosteroids. It would be interesting to re-analyse the effects of inhaled corticosteroids only in the patients with clearly defined COPD, preferably by a cumulative analysis in order to avoid, as far as possible, underestimations of the effects of inhaled corticosteroids by subgroup analysis of each separate study.

We have therefore performed a meta-analysis of the original individual patient data from these studies, selecting only patients with a strict diagnosis of COPD. The primary question was: "Are inhaled corticosteroids able to slow down the decline in lung function?" Secondary questions were: "What is the point in time when inhaled corticosteroids start to have a significant effect on the course of lung function?" "Is there a dose-effect relationship?" and "Which clinical characteristics predict the effect?"

\section{Methods}

SELECTION OF STUDIES FOR THE META-ANALYSIS A Medline search covering the period from 1983 to 1996 with the "free text" words "COPD", "chronic airflow obstruction", "obstructive airways disease", "chronic airflow limitation", "chronic bronchitis", "inhaled corticosteroids", "beclomethasone", "budesonide", and "fluticasone" yielded 94 references. The reference list of these studies was also checked for usable studies. We also checked Biosis (1991-1996), On Line Contents (19931996), "GLIN" (Grey Literature Netherlands, 1982-1996), The Cochrane Library, and Embase (1993-1996). No new references were found using the keywords above. Only studies with a duration of at least 24 months were considered to be long enough to assess the long term effects of inhaled corticosteroids on the decline in lung function. Only five studies met this criterion. ${ }^{7-11}$ Three studies were published in full ${ }^{7-9}$ and two as abstracts. ${ }^{10}{ }^{11}$ In order to be able to compare the effect of inhaled corticosteroids with that of placebo, only randomised, placebo controlled clinical trials were included. $^{7910}$ Therefore, the self-controlled study of Dompeling et $a l^{8}$ and the therapeutic trial of Weir et $a l^{11}$ were not used in the meta-analysis.

DETAILS OF THE STUDIES

In table 1 patient selection criteria, method, and analysis of the three studies are summarised. Renkema et al investigated the effects of two years of treatment with inhaled budesonide $(1600 \mu \mathrm{g} /$ day $)$ versus inhaled budesonide plus prednisone ( $5 \mathrm{mg} /$ day) versus placebo on decline in lung function, symptoms, exacerbations, and drop outs in 58 non-allergic patients with moderate to severe COPD. In the French multicentre study by Derenne $e t a l^{10}$ the effects of inhaled beclomethasone $(1500 \mu \mathrm{g} /$ day $)$ versus placebo on lung function level and the duration of exacerbations were assessed during two years in 194 patients with moderate to severe COPD. Kerstjens et $a l^{9}$ investigated the effects of $800 \mu \mathrm{g}$ inhaled beclomethasone and placebo on lung function level and decline and bronchial responsiveness during 30 months in a group of 274 patients with moderate asthma or COPD. A subgroup analysis was performed in 51 patients with a symptom based diagnosis of COPD.

SELECTION OF PATIENTS FOR THE META-ANALYSIS In order to be able to exclude patients with "asthma features" in the analyses and also to maximise the contribution of individual patient data, we used the original clinical data.

Firstly, rigid diagnostic criteria were framed based on the most recent guidelines on COPD. ${ }^{12}$ The protocols and data bases of the three studies concerned were then collected. Thirdly, the investigators of the studies were sent an output of the baseline characteristics and follow up data of their own study in order to avoid misinterpretations of their study data.

Inclusion criteria for individual patients in the meta-analysis

(1) Pulmonary symptoms compatible with the diagnosis of COPD (chronic breathlessness especially on exertion and/or (productive) cough during $\geqslant 3$ months per year in two successive years).

(2) Age 40 and over.

(3) $\mathrm{FEV}_{1}$ following treatment with $\beta_{2}$ agonist ( $\geqslant 400 \mu \mathrm{g}$ salbutamol or $\geqslant 500 \mu \mathrm{g}$ terbutaline) $\leqslant \mathrm{FEV}_{1}$ predicted $-1.64 \mathrm{SD}$.

(4) Bronchodilator response to $\beta_{2}$ agonist ( $\geqslant 400 \mu \mathrm{g}$ salbutamol or $\geqslant 500 \mu \mathrm{g}$ terbutaline) $\leqslant 9 \%$ of $\mathrm{FEV}_{1}$ predicted.

(5) Previous or current smoker.

Exclusion criteria for individual patients in the meta-analysis

(1) $\alpha_{1}$-Antitrypsin deficiency.

(2) History of asthma.

EFFECT PARAMETERS FOR THE META-ANALYSIS The primary effect parameter was prebronchodilator decline in $\mathrm{FEV}_{1}$ measured at two monthly ${ }^{7}$ or three monthly intervals ${ }^{9}{ }^{10}$ according to the recommendations of the ERS. ${ }^{13}$ All $\mathrm{FEV}_{1}$ measurements were made in a stable state - that is, in the absence of an exacerbation.

The secondary effect parameters were postbronchodilator decline in $\mathrm{FEV}_{1}$, the number of drop outs, and the number of exacerbations. $\mathrm{FEV}_{1}$ after inhalation of ipratropium bromide was not assessed in all studies so only post- $\beta_{2}$ agonist $\mathrm{FEV}_{1}$ values were used. In two studies $\mathrm{FEV}_{1}$ following treatment with $\beta_{2}$ agonist was only assessed annually ${ }^{710}$ and in one study six monthly. ${ }^{9}$ In the study by Kerstjens et $a l^{9}$ a higher dose of $\beta_{2}$ agonist was used $(1 \mathrm{mg}$ terbutaline) than in the other studies $(500 \mu \mathrm{g}$ terbutaline $^{7}$ and $400 \mu \mathrm{g}$ salbutamol $\left.{ }^{10}\right)$. Because of these differences within the studies in 
frequency, dosage, and type of bronchodilator used to measure postbronchodilator $\mathrm{FEV}_{1}$, the prebronchodilator but not the postbronchodilator $\mathrm{FEV}_{1}$ was used as the primary effect parameter in the meta-analysis.

In all three studies the number of drop outs and the reasons for drop out were recorded. The reasons for drop out were divided into "worsening of disease", "adverse effects", and "other" (personal reasons, unspecified reasons).

The number of exacerbations was recorded in all three studies. An exacerbation was defined similarly - that is, a doctor's diagnosis of increasing respiratory symptoms requiring a short course of systemic corticosteroids ${ }^{79}$ and/or antibiotics. ${ }^{10}$

Bronchial hyperresponsiveness was not used as a dependent variable or as a determinant of corticosteroid response because this clinical characteristic was not assessed in all studies. Also symptoms were not used as dependent variables because of too large variations in registration between the studies.

\section{BASELINE CHARACTERISTICS FOR THE}

META-ANALYSIS

The continuous variables were age, height, $\mathrm{FEV}_{1}$ (litres), $\mathrm{FEV}_{1}$ (expressed as a percentage of $\mathrm{FEV}_{1}$ predicted), $\mathrm{FEV}_{1} / \mathrm{IVC}(\%)$, airway reversibility (bronchodilator response to $\beta_{2}$ agonist expressed as a percentage of $\mathrm{FEV}_{1}$ predicted), smoking history (number of pack years (cigarettes/day $\times$ years smoked divided by 20 )), number of cigarettes/day, and allergy (total $\mathrm{IgE}$, expressed as IU/ml). Dichotomic variables were sex, smoker (current/ex), regular use of anticholinergics, $\beta_{2}$ agonists, theophylline, mucolytics or almitrine (Vectarion, a respiratory stimulant).

\section{ANALYSIS OF DATA}

The SAS statistical package was used in all analyses. ${ }^{14}$ IgE values were $\log _{10}(x+1)$ transformed in the analysis. The main independent variable was the inhaled corticosteroid versus placebo. In the study by Kerstjens et al patients were treated with $800 \mu \mathrm{g}$ beclomethasone, ${ }^{9}$ in the other studies with $1500 \mu \mathrm{g}$ beclomethasone or $1600 \mu \mathrm{g}$ budesonide. ${ }^{710}$ Dosages of $1500 \mu \mathrm{g}$ beclomethasone and $1600 \mu \mathrm{g}$ budesonide were considered as equal dosages for analytical purposes. The prednisone + budesonide group in the study by Renkema et al was excluded from analysis as it was presumed that the effects of oral corticosteroids, if present, would overrule the effects of inhaled corticosteroids. The

Table 1 The three placebo controlled trials on the long term effects of inhaled corticosteroids in COPD: inclusion and exclusion criteria, method, and analysis

\begin{tabular}{|c|c|c|c|}
\hline & Renkema et al ${ }^{7}$ & Derenne et $a l^{10}$ & Kerstjens et al $l^{9}$ (subgroup) \\
\hline Inclusion criteria & $\begin{array}{l}\text { Clinical diagnosis of COPD based on } \\
\text { history (persistent dyspnoea without } \\
\text { sudden attacks of dyspnoea; } \mathrm{FEV}_{1}<80 \% \\
\text { pred; } \mathrm{RV}>100 \% \text { pred; specific } \\
\text { compliance }\left(\mathrm{C}_{\mathrm{sp}} \text { ) }>100 \% \text { pred after }\right. \\
\text { bronchodilation; no signs of allergy } \\
\text { (negative skin test results), total serum } \\
\text { IgE }<200 \mathrm{IU} / \mathrm{ml} \text {, eosinophils in } \\
\text { peripheral blood }<250 \times 10^{3} / \mathrm{ml} \text {; stable } \\
\text { phase of disease; } \alpha_{1} \text {-antitrypsin within } \\
\text { normal range; (ex)-smoker }\end{array}$ & $\begin{array}{l}\text { Age } \leqslant 75 \text {; “chronic bronchitis"; } \mathrm{FEV}_{1} \\
30-60 \% \text { pred; revFEV } \mathrm{F}_{1}<10 \% \text { pred; } \mathrm{PaO}_{2} \\
>55 \mathrm{~mm} \mathrm{Hg} \text {; usual treatment without } \\
\text { corticosteroid; no exacerbation in the last } \\
\text { three months; written informed consent }\end{array}$ & $\begin{array}{l}\text { Age 18-60; "symptom-based diagnosis of } \\
\text { COPD"; FEV }{ }_{1}<\mathrm{FEV}_{1} \text { pred }-1.64 \mathrm{SD} \text { and } \\
>1.21 ; \mathrm{PC}_{20} \text { histamine } \leqslant 8 \mathrm{mg} / \mathrm{ml}\end{array}$ \\
\hline Exclusion criteria & $\begin{array}{l}\text { Age } \geqslant 70 \text {; continuous corticosteroid } \\
\text { therapy; severe concomitant disease }\end{array}$ & $\begin{array}{l}\text { Other pulmonary diseases; } \\
\text { corticosteroids past } 15 \text { days; unable to } \\
\text { follow protocol; pregnant or lactating } \\
\text { women; stomach ulcer without treatment, } \\
\text { pulmonary tuberculosis; IgE }>200 \mathrm{IU} / \mathrm{ml} \\
\text { and eosinophils }>500 \times 10^{3} / \mathrm{ml}\end{array}$ & $\begin{array}{l}\text { Maintenance treatment with } \\
\text { corticosteroids; asthmatic attacks }\end{array}$ \\
\hline Setting & Clinical, one centre & Clinical, multicentre & Clinical, multicentre \\
\hline Design & $\begin{array}{l}\text { Double blind, placebo controlled, } 3 \\
\text { parallel arms }\end{array}$ & $\begin{array}{l}\text { Double blind, placebo controlled, } 2 \\
\text { parallel arms }\end{array}$ & $\begin{array}{l}\text { Double blind, placebo controlled, } 3 \\
\text { parallel arms }\end{array}$ \\
\hline Duration of study & 24 months & 24 months & 30 months \\
\hline Study drugs & $\begin{array}{l}\text { Bud } 800 \mu \mathrm{g} \text { bd MDI through Nebuhaler } \\
+ \text { plac } 1 \mathrm{dd} \text { versus bud } 800 \mu \mathrm{g} \text { bd }+ \text { pred } \\
5 \mathrm{mg} 1 \mathrm{dd} \text { versus plac bd }+ \text { plac } 1 \mathrm{dd}\end{array}$ & Becl $1500 \mu \mathrm{g}$ MDI versus plac & $\begin{array}{l}\text { Terb } 2 \mathrm{mg}+\text { becl } 800 \mu \mathrm{g} \text { MDI versus } \\
\text { terb } 2 \mathrm{mg}+\text { ipra } 160 \mu \mathrm{g} \text { versus terb } 2 \mathrm{mg} \\
+ \text { plac }\end{array}$ \\
\hline Concomitant drugs & $\begin{array}{l}\text { Anticholinergics, } \beta_{2} \text { agonists, theophylline } \\
\text { or antihistamines }\end{array}$ & $\begin{array}{l}\text { Anticholinergics, } \beta_{2} \text { agonists, } \\
\text { theophylline, mucolytics, almitrine }\end{array}$ & Salbutamol $400 \mu \mathrm{g}$ on demand \\
\hline Outcome & $\begin{array}{l}\mathrm{FEV}_{1} \text { decline; symptoms; duration of } \\
\text { exacerbations }\end{array}$ & $\begin{array}{l}\text { Level of } \mathrm{FEV}_{1} \text {; level of PEF; duration of } \\
\text { corticosteroid course }\end{array}$ & $\begin{array}{l}\text { Drop outs; level of } \mathrm{FEV}_{1} ; \mathrm{FEV}_{1} \text { decline; } \\
\text { level of } \mathrm{PC}_{20}\end{array}$ \\
\hline Criteria pulmonary dropout & $\begin{array}{l}\geqslant 3 \text { exacerbations within } 3 \text { consecutive } \\
\text { months; severe progressive deterioration } \\
\text { of lung function level }\end{array}$ & Insufficient effectiveness & $\begin{array}{l}\text { Doctor's initiative: }>2 \text { corticosteroid } \\
\text { courses } / 3 \text { months or }>4 / \text { year; patient's } \\
\text { initiative: }>>\text { symptoms }\end{array}$ \\
\hline Definition exacerbation & $\begin{array}{l}\text { Increased complaints of dyspnoea and/or } \\
\text { cough and/or sputum with(out) fever }\end{array}$ & $\begin{array}{l}\text { (1) Increase in dyspnoea and/or (2) } \\
\text { purulent sputum and fever }\end{array}$ & $\begin{array}{l}\text { Increased symptoms and }>4 \text { additional } \\
\text { salbutamol/day }\end{array}$ \\
\hline Treatment of exacerbation & $\begin{array}{l}7 \text { days pred ( } 35-30-25 \mathrm{mg} \text { etc), and a } \\
\text { course of antibiotics if necessary }\end{array}$ & $\begin{array}{l}\text { (1) Course of pred and/or (2) course of } \\
\text { antibiotics } \leqslant 15 \text { days }\end{array}$ & 12 days pred (30-30-25-25 mg etc) \\
\hline Method of allergy measurement & Skin tests, serum IgE, eosinophil count & Serum IgE and eosinophil count & Skin tests, serum IgE, eosinophil count \\
\hline Compliance check & Weighing canisters; counting tablets & Verbal check & Weighing canisters \\
\hline \multicolumn{4}{|l|}{ Statistical analysis: } \\
\hline Overall method & Explanatory analysis of variance & $\begin{array}{l}\text { Repeated measurement analysis, } \\
\text { explanatory analysis }\end{array}$ & Analysis of variance, explanatory \\
\hline Subgroup? & No & No & Yes \\
\hline $\begin{array}{l}\text { Measurement of } \mathrm{FEV}_{1} \\
\text { decline }\end{array}$ & $\begin{array}{l}\text { Linear regression, } \geqslant 3 \text { measurements } \\
\text { needed }\end{array}$ & Repeated measurement & $\begin{array}{l}\text { Linear regression from month } 3 \text { on, } \geqslant 4 \\
\text { measurements needed }\end{array}$ \\
\hline Financial support & Astra Pharmaceuticals & GlaxoWellcome Inc. & $\begin{array}{l}\text { Netherlands Health Research Promotion } \\
\text { Program (SGO); Pharmaceutical } \\
\text { companies: Astra Pharmaceuticals, } \\
\text { Boehringer Ingelheim, Glaxo }\end{array}$ \\
\hline
\end{tabular}


Table 2 Subject selection (numbers of subjects are given)

\begin{tabular}{|c|c|c|c|}
\hline & $\begin{array}{l}\text { Renkema } \\
\text { (bud 1600 } \\
\text { pg/bud+pred/ } \\
\text { plac) }\end{array}$ & $\begin{array}{l}\text { Derenne } e^{10} \text { (becl } \\
1500 \mu \mathrm{g} / \text { plac) }\end{array}$ & $\begin{array}{l}\text { Kerstjens }{ }^{9} \text { (becl } \\
800 \mu \mathrm{g} / \text { ipra/plac) }\end{array}$ \\
\hline Original number & $\begin{array}{l}\text { Total: } 58 \\
(21 / 19 / 18)\end{array}$ & $\begin{array}{l}\text { Total: } 194 \\
(100 / 94)\end{array}$ & $\begin{array}{l}\text { Total: } 51 \\
(19 / 11 / 21)\end{array}$ \\
\hline \multicolumn{4}{|l|}{ Meeting inclusion criteria meta-analysis: } \\
\hline COPD & 58 & 194 & 51 \\
\hline Age $>40$ years & 55 & 192 & 39 \\
\hline \multicolumn{4}{|l|}{$\mathrm{FEV}_{1}$ post $\beta_{2}$ agonist $<\mathrm{FEV}_{1}$ pred } \\
\hline$-1.64 \mathrm{SD}$ & 47 & 185 & 29 \\
\hline Airway reversibility $\leqslant 9 \%$ pred $\mathrm{FEV}_{1}$ & 43 & 178 & 29 \\
\hline (Ex-)smokers (>0 pack years) & 53 & 173 & 51 \\
\hline Not meeting 1 inclusion criterion & 22 & 36 & 25 \\
\hline Not meeting 2 inclusion criteria & 6 & 6 & 8 \\
\hline Not meeting 3 inclusion criteria & 0 & 0 & 3 \\
\hline Not meeting $\geqslant 4$ inclusion criteria & 0 & 0 & 0 \\
\hline \multicolumn{4}{|l|}{ Meeting exclusion criteria meta-analysis: } \\
\hline$\alpha_{1}$-Antitrypsin deficiency & 0 & 0 & 0 \\
\hline Asthma history & 0 & 0 & 0 \\
\hline Eligible for meta-analysis & $30\left(6 / 14^{\star} / 10\right)$ & $152(81 / 71)$ & $15(8 / 3+/ 4)$ \\
\hline
\end{tabular}

bud $=$ budesonide $;$ plac $=$ placebo $;$ pred $=$ prednisone $;$ becl $=$ beclomethasone $;$ ipra $=$ ipratropium . *Excluded from analysis because of treatment with oral corticosteroids.

†Considered as "placebo" in the meta-analysis.

patients in the study by Kerstjens et al who were treated with ipratropium bromide were considered as a placebo group since no long term effects other than the acute bronchodilating effect of ipratropium bromide were observed. ${ }^{15}$

Since the duration of the study by Kerstjens et al was 30 months and the two other studies took 24 months, only patient data up to 24 months of study were used.

In the study by Renkema et al two monthly $\mathrm{FEV}_{1}$ measurements were performed compared with three monthly measurements in the two other studies. In all the analyses the average individual $\mathrm{FEV}_{1}$ values of the measurements of 2 and 4, 8 and 10, 14 and 16, and 20 and 22 months were therefore used as estimates for the $\mathrm{FEV}_{1}$ at 3, 9, 15 and 21 months, respectively.

Differences in drop out percentages and reasons for drop out during the trial between the inhaled corticosteroid and the placebo groups were tested with the $\chi^{2}$ test. Differences in the number of exacerbations per year

Table 3 Mean (SD) baseline characteristics and exacerbation and drop out rates of patients using inhaled corticosteroids (irrespective of the dose) or placebo

\begin{tabular}{|c|c|c|}
\hline & $\begin{array}{l}\text { Inhaled corticosteroids } \\
(n=95)\end{array}$ & Placebo $(n=88)$ \\
\hline Age (years) & $61(7)$ & $61(7)$ \\
\hline Height $(\mathrm{cm})$ & $170(7)$ & $168(7)$ \\
\hline Male (n) & 89 & 79 \\
\hline $\mathrm{FEV}_{1}(1)$ & $1.42(0.47)$ & $1.30(0.38)$ \\
\hline FEV (\% pred) & $46(11)$ & $44(10)$ \\
\hline $\mathrm{FEV}_{1} / \mathrm{IVC}(\%)$ & $49(13)$ & $47(11)$ \\
\hline Airway reversibility ( $\%$ of $\mathrm{FEV}_{1}$ pred) & $3.2(2.7)$ & $2.9(2.5)$ \\
\hline Pack years & $40(25)$ & $43(24)$ \\
\hline Smoker (current/ex) & $32 / 63$ & $34 / 54$ \\
\hline Cigarettes/day (n) & $17(12)$ & $17(11)$ \\
\hline $\log _{10}(\mathrm{IgE}+1)(\mathrm{IU} / \mathrm{ml})$ & $1.71(0.59)$ & $1.67(0.50)$ \\
\hline \multicolumn{3}{|l|}{ Regular use of (\% of patients): } \\
\hline Anticholinergics & 25 & 32 \\
\hline Short acting $\beta_{2}$ agonists & 60 & 62 \\
\hline Theophylline & 56 & 53 \\
\hline Mucolytics & 33 & 40 \\
\hline Almitrine & 10 & 13 \\
\hline \multicolumn{3}{|l|}{ During the study: } \\
\hline Exacerbations/year & $0.9(0.9)$ & $1.0(1.3)$ \\
\hline Drop outs $(\mathrm{n})$ & 35 & 29 \\
\hline \multicolumn{3}{|l|}{ Reason for drop out (n): } \\
\hline Worsening of the disease & 4 & 9 \\
\hline Adverse effects & 17 & 12 \\
\hline Other reasons & 14 & 8 \\
\hline
\end{tabular}

between both groups were tested univariately with the Student's $t$ test.

The effect of inhaled corticosteroids (independent of the dose) on prebronchodilator and postbronchodilator $\mathrm{FEV}_{1}$ (litres) was measured with a multiple repeated measurement technique in which patient and time effects on $\mathrm{FEV}_{1}$ were separately investigated in an intention-to-treat analysis. Preliminary analysis demonstrated no measurement ${ }^{\star}$ treatment interaction. For that reason a random coefficient model was chosen in which all available individual time points of $\mathrm{FEV}_{1}$ measurements were incorporated and analysed. In a first model the effect of inhaled corticosteroids, irrespective of the dose used, on the course of $\mathrm{FEV}_{1}$ was compared with placebo. In a second analysis the dose effects of the inhaled corticosteroid ( $800 \mu \mathrm{g}$ beclomethasone ("low dose") versus $1500 \mu \mathrm{g}$ beclomethasone or $1600 \mu \mathrm{g}$ budesonide ("high dose")) on the course of $\mathrm{FEV}_{1}$ were investigated by adding one dummy.

In order to correct for possible confounders and to be able to assess which clinical characteristics may predict the influence of inhaled corticosteroids on the change in $\mathrm{FEV}_{1}$, the baseline variables of age, height, sex, $\mathrm{FEV}_{1}$, airway reversibility, pack years, smoking, IgE, anticholinergics, $\beta_{2}$ agonists, theophylline, mucolytics, and almitrine were introduced into the model. The number of exacerbations during the study was also introduced into the model. In addition, data on the number of cigarettes smoked daily during the study (assessed at each visit) were incorporated into the analysis at each time point of measurement. Only baseline data of the number of cigarettes smoked daily were available from the study of Renkema et al. However, smoking behaviour was shown to be remarkably constant during the study. ${ }^{7}$ Compliance rates and a complete registration of all adverse effects during the studies were not available for all three studies.

First, all possible interaction terms of the independent variables with treatment were incorporated into the model. Secondly, in a backwards procedure variables with the highest

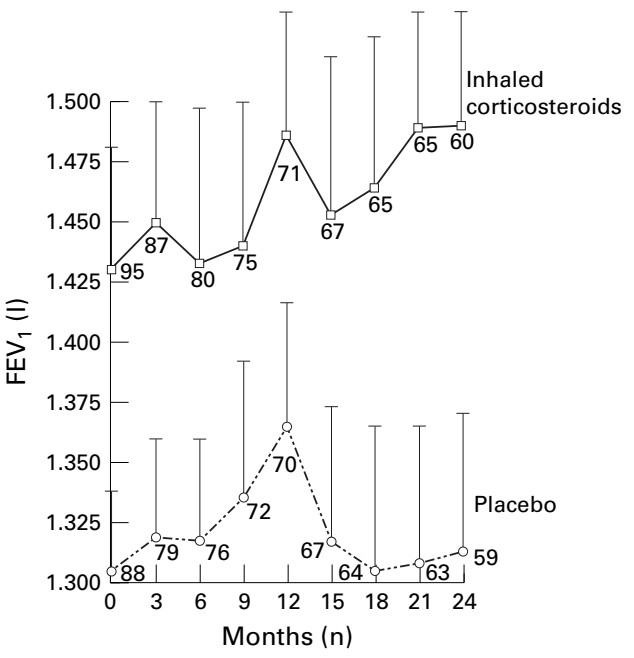

Figure 1 Course of prebronchodilator FEV $V_{1}$ in the inhaled corticosteroid and placebo groups. SE values and numbers of subjects participating in the study at each point of measurement are presented. 
Table 4 Influence of inhaled corticosteroids compared with placebo on the change in prebronchodilator and postbronchodilator $F E V_{1}$ (l) by repeated measurement analysis. The model presents only variables with $p \leqslant 0.05$

\begin{tabular}{|c|c|c|c|}
\hline & $\begin{array}{l}\text { Two-year } \\
\text { estimate (I/year) }\end{array}$ & $S E$ & $\begin{array}{l}p \text { value } \\
(\operatorname{Pr}>F)\end{array}$ \\
\hline \multicolumn{4}{|l|}{ Prebronchodilator: } \\
\hline $\begin{array}{l}\text { Treatment effect (inhaled corticosteroids versus } \\
\text { placebo }(n=183)\end{array}$ & +0.034 & 0.015 & 0.026 \\
\hline $\mathrm{FEV}_{1}$ baseline (1) & +0.97 & 0.027 & 0.0001 \\
\hline$\beta_{2}$ agonists (yes) & +0.063 & 0.025 & 0.012 \\
\hline Almitrine (yes) & -0.075 & 0.038 & 0.048 \\
\hline \multicolumn{4}{|l|}{ Postbronchodilator: } \\
\hline $\begin{array}{l}\text { Treatment effect (inhaled corticosteroids versus } \\
\text { placebo, } n=183 \text { ) }\end{array}$ & +0.039 & 0.023 & 0.095 \\
\hline Height (m) & +0.64 & 0.222 & 0.004 \\
\hline Reversibility $\mathrm{FEV}_{1}$ (as \% of predicted $\mathrm{FEV}_{1}$ ) & +0.014 & 0.005 & 0.003 \\
\hline $\mathrm{FEV}_{1}$ baseline (1) & +0.92 & 0.036 & 0.0001 \\
\hline$\beta_{2}$ agonists (yes) & +0.058 & 0.027 & 0.034 \\
\hline
\end{tabular}

$\mathrm{p}$ value were subsequently deleted until only variables with $\mathrm{p} \leqslant 0.05$ remained.

No analysis was performed with linear regression based measurement of $\mathrm{FEV}_{1}$ decline. Preliminary analysis demonstrated a non-linear course in the $\mathrm{FEV}_{1}$ : the explained variance of individual linear regression analysis of $\mathrm{FEV}_{1}$ was only $24 \%$ on average (SD $24 \%$, range $0-99 \%)$.

\section{Results}

\section{SUBJECT SELECTION}

The selection procedures of subjects for the meta-analysis are presented in table 2. The most important reasons for exclusion were "mild obstruction" $\left(\mathrm{FEV}_{1} \geqslant \mathrm{FEV}_{1}\right.$ predicted -1.64 SD, 42 of original 303 patients) or "reversible obstruction" ( $>9 \%$ of the $\mathrm{FEV}_{1}$ predicted, 53 of 303 patients). Twenty eight of the 58 subjects ( $48 \%$ ) in the study by Renkema et al were excluded from the meta-analysis, 15 because of reversible obstruction. From the study by Derenne et al $42(17 \%)$ of the 194 patients were excluded from the meta-analysis, 21 because they were never-smokers. Subjects in the study by Kerstjens et al were younger and had less severe airway obstruction than in the other two studies. Therefore, only 15 (29\%) of the 51 subjects in this study were eligible for the meta-analysis. Within each study the baseline characteristics between the patients in the inhaled corticosteroid group and the placebo group eligible for the meta-analysis did not differ significantly in all relevant parameters.

BASELINE DATA

Table 3 shows the combined baseline characteristics of the 183 subjects selected. No statistically significant differences between the inhaled corticosteroid group and the placebo group were present in the relevant parameters.

EFFECTS OF INHALED CORTICOSTEROIDS ON FEV ${ }_{1}$ (REPEATED MEASUREMENT ANALYSIS)

In fig 1 the effect of two years of treatment with inhaled corticosteroids, irrespective of their dose, on the prebronchodilator $\mathrm{FEV}_{1}$ is presented versus placebo, and in table 4 the results are presented after adjustment of variables with $\mathrm{p} \leqslant 0.05$. The estimate was $+0.0341 /$ year $(95 \%$ confidence interval (CI) 0.005 to 0.063 ), which was statistically significant $(\mathrm{p}=0.026)$. If the dose of inhaled corticosteroids was

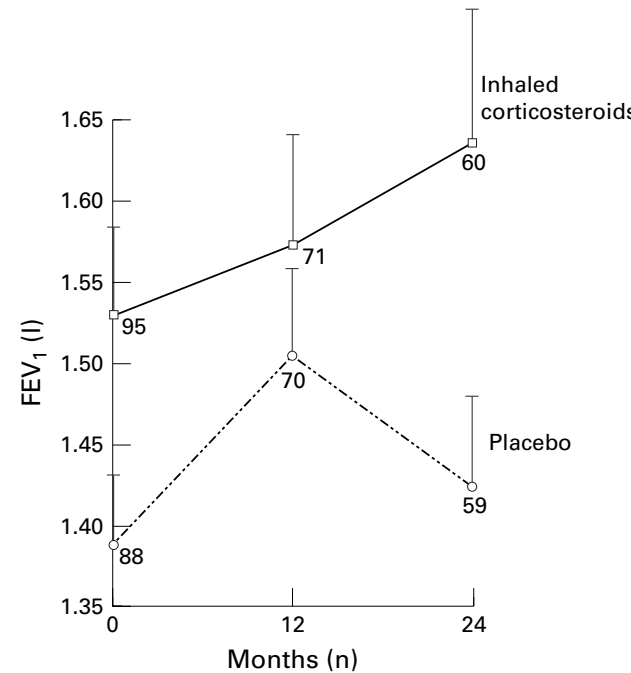

Figure 2 Course of postbronchodilator FEV of the inhaled corticosteroid and placebo groups. SE values and numbers of subjects participating in the study at each point of measurement are presented.

included in the model, the estimate was $+0.0021 /$ year $(95 \% \mathrm{CI}-0.061$ to 0.065$)$ for the low dose of inhaled corticosteroids and $+0.0391 /$ year $(95 \%$ CI 0.008 to 0.070$)$ for the high dose $(\mathrm{p}=0.043)$.

The same procedure with postbronchodilator $\mathrm{FEV}_{1}$ showed a two year treatment effect for the inhaled corticosteroid group versus the placebo group of $+0.0391 /$ year $(95 \%$ CI -0.0061 to $0.0841, \mathrm{p}=0.095$ ) (table 4 , fig 2 ), which was maintained only in the high dose group if the dose of inhaled corticosteroids was taken into account.

DETERMINANTS OF LUNG FUNCTION SLOPE AND CORTICOSTEROID RESPONSE

Table 4 shows an independent effect of the following two variables on a beneficial course in $\mathrm{FEV}_{1}$ : the use of short acting $\beta_{2}$ agonists and a higher baseline $\mathrm{FEV}_{1}$. No interaction of any of the variables analysed with the inhaled corticosteroid treatment was observed.

EFFECT OF INHALED CORTICOSTEROIDS ON EXACERBATIONS AND DROP OUTS

During the study the mean (SD) number of exacerbations per year was $0.9(0.9)$ in the inhaled corticosteroid group and 1.0 (1.3) in the placebo group ( $p>0.05$; table 3$)$. The drop out rate during the study was $36 \%$ in the inhaled corticosteroid group and $32 \%$ in the placebo group (table 3). In the placebo group twice as many patients dropped out due to worsening of the disease compared with the actively treated group (9/88 versus $4 / 95$ patients, $p=0.11)$. No patients dropped out in the low dose inhaled corticosteroid group. Comparison of the baseline characteristics between those who fulfilled the protocol and the drop outs within each trial group showed no indications of selective drop out or "survivor effect".

ADVERSE EFFECTS

In the inhaled corticosteroid group 17 of the 95 subjects dropped out because of adverse effects 
compared with 12 of 88 in the placebo group $\left(\chi^{2}=0.62, p=0.43\right)$. All these drop outs were in the study by Derenne et al. An additional investigation of the adverse effect files of these patients showed that in six of the 95 subjects in the active group the adverse event leading to drop out may have been related to the treatment (cough, dysphonia, sore throat, anorexia, problems with taste and the nasal organ, and headache). In the placebo group the cause of drop out in two of the 88 subjects could have been related to treatment (cough, dysphonia, sore throat) $\left(\chi^{2}=1.78, \mathrm{p}=0.18\right)$. No serious adverse effects related to the treatment occurred.

\section{Discussion}

We combined the original data of three published long term intervention studies with inhaled corticosteroids in moderately severe COPD, selecting only patients with clearly defined disease. The meta-analysis showed a significant beneficial effect of inhaled corticosteroids compared with placebo on the course of the prebronchodilator $\mathrm{FEV}_{1}$ during two years of treatment $(+0.0681)$, whereas only a tendency towards an effect of inhaled corticosteroids on postbronchodilator $\mathrm{FEV}_{1}$ was shown. However, the latter results pertain to only three data points. A specific measurement ${ }^{\star}$ treatment effect was lacking. A daily dose of $1500 / 1600 \mu \mathrm{g}$ of the inhaled corticosteroid was more effective than $800 \mu \mathrm{g}$, although it should be noted that only a small number of subjects received the lower dose. No beneficial effect was observed on the exacerbation rate or drop out rate. Finally, no interaction effect of the variables assessed on the response to inhaled corticosteroids was found.

When the three original studies contributing to the meta-analysis were considered, no heterogeneity was seen in the beneficial effect of inhaled corticosteroids on the $\mathrm{FEV}_{1}$. Renkema et al demonstrated a median decline of $\mathrm{FEV}_{1}$ of $60 \mathrm{ml} /$ year in the placebo group and $30 \mathrm{ml} /$ year in the budesonide group. ${ }^{7}$ Due to large interpatient variations this difference was not significant. Kerstjens et al found the $\mathrm{FEV}_{1}$ to increase significantly by $+7.4 \quad(3.1) \%$ predicted in the beclomethasone group compared with the placebo group after the first six months of study. ${ }^{9}$ The study by Derenne et al demonstrated an improvement in $\mathrm{FEV}_{1}$ of $+1.44 \%$ from baseline in the experimental group compared with $-0.62 \%$ in the placebo group $(p=0.05)$ during the two year study. ${ }^{10}$ Subjects of these three studies who were excluded from our meta-analysis were patients who had features of asthma in addition to COPD. An interesting finding was that, although we selected only patients with clearly defined COPD for the analysis, a beneficial effect of inhaled corticosteroids on the course of $\mathrm{FEV}_{1}$ remained present.

Several shortcomings of the study should be mentioned. Firstly, we presented the results of a "re-analysis" using studies with a duration of only two years. Secondly, compliance data and the doses of concomitant drugs were not incor- porated and corrected for in the analysis. Thirdly, cost effectiveness was only assessed in the study by Kerstjens. Rutten-van Mölken et $a l^{16}$ found that "addition of an inhaled corticosteroid to a $\beta$ agonist leads to significant benefits in respiratory function and restricted activity days with relatively low additional health care costs". However, an interaction analysis in this study showed that inhaled corticosteroids were most beneficial in patients with the "classic" asthma profile (allergy, reversibility, non-smoking, and mostly young). Longer term and larger studies with more detailed registration of compliance, drug use during the trial, and cost effectiveness are therefore required to confirm the conclusions of our study.

In two retrospective studies with oral prednisone in a group of patients with moderate and severe COPD it has been suggested that the time to reach a response to oral corticosteroids is 6-24 months. ${ }^{5}$ In our meta-analysis with inhaled corticosteroids no specific time point of response was observed, but a sustained effect of inhaled corticosteroids on the course of $\mathrm{FEV}_{1}$ took place during the two years. In a self-controlled study in 26 patients with moderate COPD Dompeling et al investigated the effects of $800 \mu \mathrm{g}$ beclomethasone on the course of $\mathrm{FEV}_{1} .{ }^{8}$ The prebronchodilator $\mathrm{FEV}_{1}$ increased during the first six months of the trial with no further effect on the decline in $\mathrm{FEV}_{1}$ after that. The study by Kerstjens et al showed that a response had already been achieved after three months. ${ }^{9}$ In both studies inclusion of COPD patients with some "asthmatic features" such as airway reversibility and allergy in both studies might have contributed to this early response. Preliminary results of the EUROSCOP study, a large three year study in patients with mild COPD using $800 \mu \mathrm{g}$ budesonide, have also shown an effect of inhaled corticosteroids, especially during the first three months of the study (oral presentation, Congress of the European Respiratory Society, 1997). Further analysis is needed to show whether this early effect of inhaled corticosteroids may indicate "asthmatic features" in the group of patients with COPD selected. Moreover, in the light of the previous studies by Postma et $a \bar{l}^{6}$ with systemic corticosteroids, the delay in reaching "the response" in our study may suggest a true effect of inhaled corticosteroids on COPD.

The course of postbronchodilator $\mathrm{FEV}_{1}$ tended to differ from prebronchodilator $\mathrm{FEV}_{1}$, especially after one year and to the advantage of the placebo group. In fig 2 it appears that the $\mathrm{FEV}_{1}$ in the placebo group increased considerably after one year of the study. This may be explained partly by the fact that "all" participants (including drop outs) were plotted. The drop outs in the placebo group, most of which dropped out during the first year of the study, had a lower baseline $\mathrm{FEV}_{1} \%$ predicted than those who fulfilled the protocol of the placebo group ( $41 \%$ versus $47 \%$ of $\mathrm{FEV}_{1}$ predicted, $\mathrm{p}<0.0174)$. It was shown that the course of postbronchodilator $\mathrm{FEV}_{1}$ in patients in the 
placebo group who finished the study was reasonably stable during the first year of the study.

A daily dose of $1500 \mu \mathrm{g}$ beclomethasone or $1600 \mu \mathrm{g}$ budesonide was more effective than $800 \mu \mathrm{g}$ beclomethasone, with effects on the prebronchodilator $\mathrm{FEV}_{1}$ of $0.039 \mathrm{1}$ /year and 0.0021 /year, respectively. However, in the analysis the group of patients treated with $800 \mu \mathrm{g}$ beclomethasone was relatively small ( $\mathrm{n}$ $=8$ ) and therefore this result has to be interpreted with great caution. On the other hand, in short term studies with inhaled corticosteroids in patients with moderately severe COPD daily dosages of at least $1500 \mu \mathrm{g}$ seemed to be necessary to achieve significant improvements in $\mathrm{FEV}_{1}{ }^{4}$ Watson et al found no beneficial effects on the level of lung function in a nine month single blind follow up study with $1200 \mu \mathrm{g}$ budesonide daily. ${ }^{17}$ In a long term therapeutic trial (mean duration 26 months) of oral and inhaled corticosteroids in 121 patients with non-asthmatic chronic airway obstruction, beclomethasone $750 \mu \mathrm{g}$ twice daily seemed to slow down the decline in $\mathrm{FEV}_{1}{ }^{11}$ Unfortunately this study was not placebo controlled and is only published in abstract form. In patients with moderate asthma daily doses of $800 \mu \mathrm{g}$ inhaled corticosteroids are often sufficient to achieve disease control. In the light of our study we hypothesise that, in patients with moderate to severe COPD, differences in the type and site of inflammation in asthma and COPD might lead to the need for higher dosages of inhaled corticosteroids in COPD. In COPD the largely neutrophilic and lymphocytic inflammation seems to take place in the peripheral airways while in asthma the predominantly eosinophilic inflammation is located mainly in the central airways. ${ }^{3}$ These two considerations might explain the need for a higher dosage of inhaled corticosteroids in moderate to severe COPD compared with moderate asthma. If we consider the preliminary results of the EUROSCOP, the dosage of inhaled corticosteroids $(800 \mu \mathrm{g}$ budesonide daily) may have been too low to be sufficient. Two other large long term multicentre European studies of COPD will soon present the long term effects of a low to medium dosage of inhaled corticosteroids in mild COPD (800$1200 \mu \mathrm{g}$ budesonide daily; Copenhagen City Lung Study) and a relatively high daily dose in severe COPD (1000 $\mu \mathrm{g}$ fluticasone; ISOLDE). This may help us to understand better the minimal daily dose of inhaled corticosteroids required to prevent progression of the decline in lung function in COPD.

The beneficial course of $\mathrm{FEV}_{1}$ in patients treated with inhaled corticosteroids compared with placebo was not accompanied by a lower number of exacerbations. Bacterial superinfection is a common cause of acutely aggravating COPD. ${ }^{1}$ It might not be expected that inhaled corticosteroids protect the bronchial wall of the host against bacterial colonisation in patients with COPD. However, this result has to be treated with caution because the definition of exacerbation varied between the three studies in the meta-analysis (see table 1).
Several variables influenced the course of prebronchodilator $\mathrm{FEV}_{1}$ independently. The regular use of both oral and inhaled $\beta_{2}$ agonists was related independently to an overall change in both prebronchodilator and postbronchodilator $\mathrm{FEV}_{1}$ of +0.0631 1/year after two years. This result strongly contrasts with the general opinion that regular use of $\beta_{2}$ agonists cannot delay the progression of COPD. ${ }^{12}$ However, the route of administration, dosages, and drug names of the $\beta_{2}$ agonists were not specified in the largest study. ${ }^{10}$ Our result therefore has to be interpreted with caution.

Contrary to others, ${ }^{4}$ the meta-analysis did not show a relationship between higher levels of IgE or airway reversibility and a better response to inhaled corticosteroids in COPD. As already mentioned, allergy was an exclusion criterion in two of the three studies. Also, subjects with reversible airway obstruction were excluded from the analysis. Both factors may explain the absence of an interaction effect of relatively low levels of $\operatorname{IgE}$ and airway reversibility on the response to inhaled corticosteroids. No other variables interacted with the effect of inhaled corticosteroids.

Up to now, smoking cessation has been shown to be the only intervention able to improve the long term morbidity and mortality due to COPD, next to supplemental oxygen in hypoxaemic patients. ${ }^{1215}$ The results of this study indicate that, in patients with moderate to severe COPD (FEV $145-55 \%$ of predicted), relatively high doses of inhaled corticosteroids $(\geqslant 1500 \mu \mathrm{g})$ may also improve the long term prognosis. Dosages above $1 \mathrm{mg}$ may cause systemic side effects, as assessed by cortisol levels. ${ }^{18}$ However, an additional investigation of the side effect reports from the studies by Derenne and Renkema with high doses of inhaled corticosteroids demonstrated symptoms which could have been related to the treatment (especially cough and dysphonia) in approximately $20 \%$ of the subjects, with no difference between the active and the placebo groups. There were no indications of high intolerability of the study drug in any of the three studies, not even with high doses.

In conclusion, this is the first study of a group of patients with strictly defined moderate to severe COPD showing a preservation of the $\mathrm{FEV}_{1}$ during two years of treatment with relatively high dosages of inhaled corticosteroids $(1500 \mu \mathrm{g}$ beclomethasone or $1600 \mu \mathrm{g}$ budesonide daily).

We thank The Dutch Government Organization for Scientific Research for financial support and are grateful to Mr P M R Jansen for his computer assistance in the search of the literature.

1 American Thoracic Society. Standards for the diagnosis and care of patients with chronic obstructive pulmonary disease. Am f Respir Crit Care Med 1995;152:S77-121.

2 Siafakas NM, Vermeire P, Pride NB, et al. Optimal assessment and management of chronic obstructive pulmonary disease (COPD). The European Respiratory Society Task Force. Eur Respir $\mathcal{F}$ 1995;8:1398-420.

3 Lacoste JY, Bousquet J, Chanez P, et al. Eosinophilic and Lacoste JY, Bousquet J, Chanez $\mathrm{P}$, et al. Eosinophilic and neutrophilic inflammation in asthma, chronic bronchitis, and chronic obstructive pulmonary disease. F Allergy Clin Immunol 1993,92:537-48.

4 Schayck CP van, Grunsven PM van, Dekhuijzen PNR. Do patients with COPD benefit from treatment with inhaled corticosteroids? Eur Respir f 1996;9:1969-72. 
5 Postma DS, Peters I, Steenhuis EJ, et al. Moderately severe chronic airflow obstruction. Can corticosteroids slow down chronic airflow obstruction. Can corticost

obstruction? Eur Respir f 1988;1:22-6.
6 Postma DS, Steenhuis EJ, van der Weele LT, et al. Severe chronic airflow obstruction: can corticosteroids slow down progression? Eur f Respir Dis 1985;67:56-64.

7 Renkema TE, Schouten JP, Koeter GH, et al. Effects of long-term treatment with corticosteroids in COPD. Ches 1996;109:1156-62.

8 Dompeling E, Schayck CP van, Grunsven PM van, et al. Slowing the deterioration of asthma and chronic obstructive pulmonary disease observed during bronchodilator therapy by adding inhaled corticosteroids. A 4-year prospective study. Ann Intern Med 1993;118:770-8.

9 Kerstjens HA, Brand PL, Hughes MD, et al. A comparison of bronchodilator therapy with or without inhaled corticosteroid therapy for obstructive airways disease. $N$ Engl f Med 1992;327:1413-9.

10 Derenne JP. Effects of high dose inhaled beclomethasone in the rate of decline in $\mathrm{FEV}_{1}$ in patients with chronic obstructive pulmonary disease: results of a 2 years prospective multive pulmonary disease: results of a 2 years prospective mu-
ticentre study. Am f Respir Crit Care Med 1995;151:A463.

ticentre study. Am f Respir Crit Care Med 1995;151:A463.
11 Weir DC, Robertson AS, Gove RI, et al. Non-asthmatic chronic airflow obstruction: can inhaled corticosteroids slow down disease progression? Thorax 1988;43:857P.
12 Kerstjens HA, Overbeek SE, Schouten JP, et al. Airways hyperresponsiveness, bronchodilator response, allergy and smoking predict improvement in $\mathrm{FEV}_{1}$ during long-term inhaled corticosteroid treatment. Eur Respir 7 1993;6:86876.

13 Quanjer Ph, Tammeling GJ, Cotes JE, et al. Lung volumes and forced ventilatory flows. Eur Respir 7 1993;6:5-40.

14 Wolfinger R, ed. The mixed procedure. SAS Technical Report P-229. 1992: Chapter 16.

15 Anthonisen NR, Connett JE, Kiley JP, et al. Effects of smoking intervention and the use of an inhaled anticholinergic bronchodilator on the rate of decline of $\mathrm{FEV}_{1}$. The Lung Health Study. $7 A M A$ 1994;272:1497-505.

16 Rutten-van Mölken MP, Doorslaer EK van, Jansen MC, et al. Costs and effects of inhaled corticosteroids and bronchodilators in asthma and chronic obstructive pulmonary disease. Am F Respir Crit Care Med 1995;151:975-82.

17 Watson A, Lim TK, Joyce $\mathrm{H}$, et al. Failure of inhaled corticosteroids to modify bronchoconstrictor or bronchodilator responsiveness in middle-aged smokers with mild airflow obstruction. Chest 1992;101:350-5.

18 Geddes DM. Inhaled corticosteroids: benefits and risks. Thorax 1992;47:404-7. 